Prepared in cooperation with the National Park Service

\title{
Main-Stem Seepage and Base-Flow Recession Time Constants in the Niobrara National Scenic River Basin, Nebraska, 2016-18
}

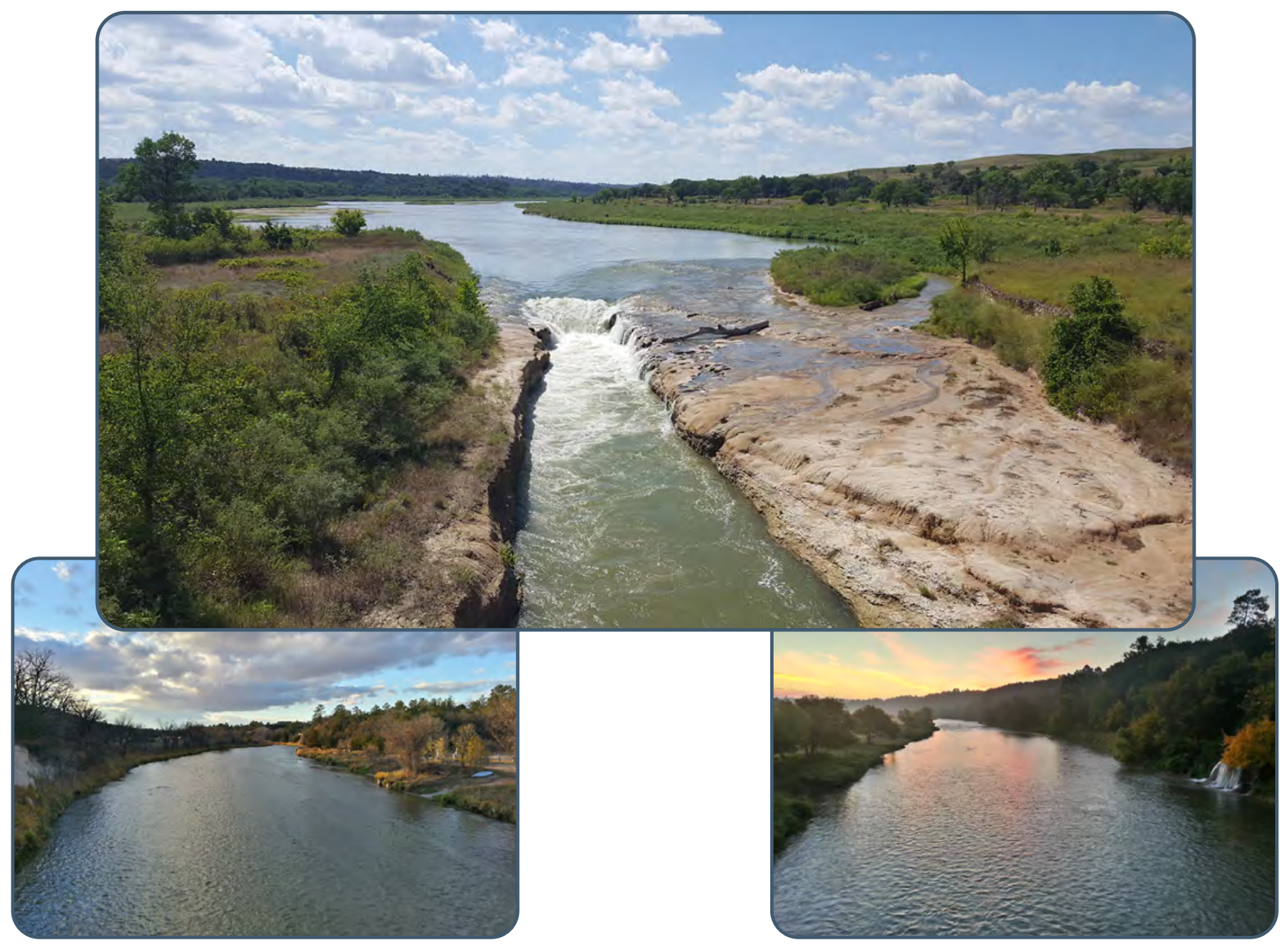

Scientific Investigations Report 2021-5102 


\section{Front cover:}

Top, Photograph showing Niobrara River looking upstream from the Norden Avenue Bridge at Niobrara River near Norden, Nebraska (06462000), taken July 31, 2017.

Bottom left, Photograph showing Niobrara River looking upstream from Berry Bridge at Niobrara River near Sparks, Nebraska (06461500), taken October 27, 2014.

Bottom right, Photograph showing Niobrara River and Berry Falls looking downstream from Berry Bridge at Niobrara River near Sparks, Nebraska (06461500), taken September 19, 2014.

Photographs by Matthew Moser, U.S. Geological Survey. 


\section{Main-Stem Seepage and Base-Flow Recession Time Constants in the Niobrara National Scenic River Basin, Nebraska, 2016-18}

By Kellan R. Strauch and Philip J. Soenksen

Prepared in cooperation with the National Park Service

Scientific Investigations Report 2021-5102 


\section{U.S. Geological Survey, Reston, Virginia: 2022}

For more information on the USGS - the Federal source for science about the Earth, its natural and living resources, natural hazards, and the environment—visit https://www.usgs.gov or call 1-888-ASK-USGS.

For an overview of USGS information products, including maps, imagery, and publications, visit https://store.usgs.gov/.

Any use of trade, firm, or product names is for descriptive purposes only and does not imply endorsement by the U.S. Government.

Although this information product, for the most part, is in the public domain, it also may contain copyrighted materials as noted in the text. Permission to reproduce copyrighted items must be secured from the copyright owner.

Suggested citation:

Strauch, K.R., and Soenksen, P.J., 2022, Main-stem seepage and base-flow recession time constants in the Niobrara National Scenic River Basin, Nebraska, 2016-18: U.S. Geological Survey Scientific Investigations Report 2021-5102, 17 p., https://doi.org/10.3133/sir20215102.

Associated data for this publication:

Strauch, K.R., and Soenksen, P.J., 2022, Datasets used to map the base-flow recession time constants in the Niobrara National Scenic River in Nebraska, 2016-18: U.S. Geological Survey data release, https://doi.org/10.5066/P9PDP1BI.

U.S. Geological Survey, 2020, USGS water data for the Nation: U.S. Geological Survey National Water Information System database, https://doi.org/10.5066/F7P55KJN.

ISSN 2328-0328 (online) 


\section{Acknowledgments}

We thank Gordon Warrick and other National Park Service personnel for assisting with streamflow measurements, aiding with landowner coordination, and providing invaluable local expertise. We thank the Fort Niobrara National Wildlife Refuge for granting access to the property they manage and for providing assistance during the study. We also thank landowners for graciously allowing access to their property during data collection. 



\section{Contents}

Acknowledgments ……...................................................................................................................

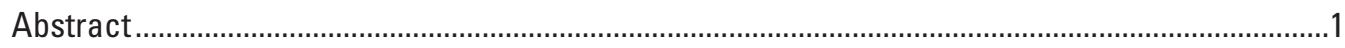

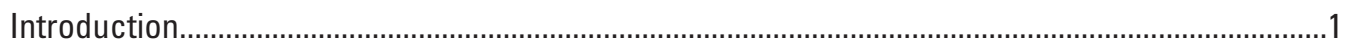

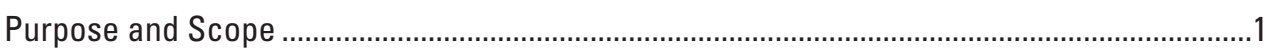

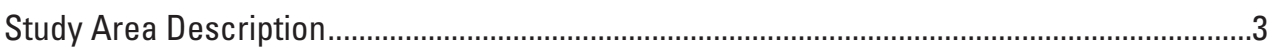

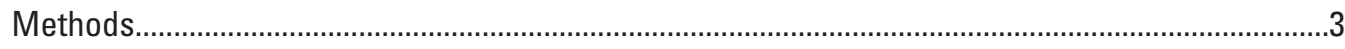

Main-Stem Seepage Conditions and Calculations ………........................................................

Base-Flow Conditions and Temporal Variability ............................................................

Streamflow Measurements and Estimated Uncertainty..................................................4

Midsection and Point-Velocity Method ................................................................

Acoustic Doppler Current Profiler and Other Methods..............................................6

Gain/Loss Calculations and Levels of Uncertainty...........................................................

Base-Flow Recession Time Constants Calculation and Kriged Map Creation............................7

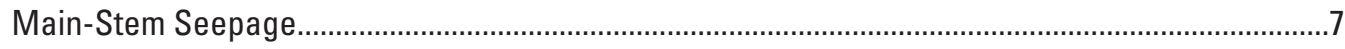

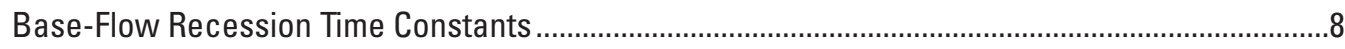

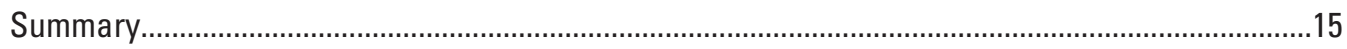

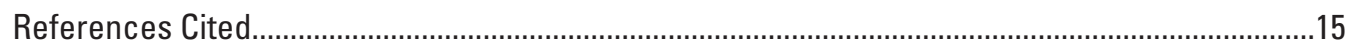

\section{Figures}

1. Map showing locations of study area, U.S. Geological Survey and Nebraska Department of Natural Resources streamflow measurement sites, and Global Historical Climatology Network precipitation gages in the Niobrara River Basin ............2

2. Graphs showing streamgage streamflow record and daily precipitation during October 1-31, 2016.

3. Graph showing Niobrara River streamflow along the geologic reach from Norden Bridge to Meadville to State Highway 7 to State Highway 137 bridge, as reconstructed from main-stem and tributary inflow measurements, computed main-stem seepage gains/losses, and computed seepage gain/loss rates during the base-flow seepage study, October 27-28, 2016

4. Map showing location of calculated tau values and map of filled tau contours for sites in the Niobrara National Scenic River study area, July 1-0ctober 31, 2016-18

\section{Tables}

1. Streamflow for selected Niobrara River main-stem and tributary sites from Norden Bridge near Norden, Nebraska, to State Highway 137 bridge at Mariaville, Nebr., during a seepage study, October 27-28, 2016.

2. Mean rates of streamflow gain or loss in the main stem summarized for total flow, tributary inflows, and main-stem seepage, with the interval of uncertainty, for geologic reach 3 of Niobrara River, April 21-30, 1980; November 9-13, 2009; and October 27-28, 2016. 
3. Calculated tau values at streamgage locations in the Niobrara National Scenic River study area, July 1-0ctober 31, 2016-18.

\section{Conversion Factors}

U.S. customary units to International System of Units

\begin{tabular}{lcl}
\hline \multicolumn{1}{c}{ Multiply } & By & To obtain \\
\hline inch (in.) & Length & \\
inch (in.) & 2.54 & centimeter $(\mathrm{cm})$ \\
mile (mi) & 25.4 & millimeter $(\mathrm{mm})$ \\
\hline & 1.609 & kilometer $(\mathrm{km})$ \\
\hline square mile $\left(\mathrm{mi}^{2}\right)$ & Area & \\
square mile $\left(\mathrm{mi}^{2}\right)$ & 259.0 & hectare $(\mathrm{ha})$ \\
\hline & 2.590 & square $\mathrm{kilometer}\left(\mathrm{km}^{2}\right)$ \\
\hline cubic foot per second $\left(\mathrm{ft}^{3} / \mathrm{s}\right)$ & Flow rate & \\
cubic foot per second per mile $\left(\left[\mathrm{ft}^{3} / \mathrm{s}\right] / \mathrm{mi}^{2}\right)$ & 0.0176 & cubic meter per second per kilometer \\
\end{tabular}

\section{Datum}

Horizontal coordinate information is referenced to the North American Datum of 1983 (NAD 83).

\section{Abbreviations}

ADCP acoustic Doppler current profiler

ADV acoustic Doppler velocimeter

NSR National Scenic River

tau base-flow recession time constant

USGS U.S. Geological Survey 


\title{
Main-Stem Seepage and Base-Flow Recession Time Constants in the Niobrara National Scenic River Basin, Nebraska, 2016-18
}

\author{
By Kellan R. Strauch ${ }^{1}$ and Philip J. Soenksen ${ }^{2}$
}

\section{Abstract}

The Niobrara River of northern Nebraska is a valuable water resource that sustains irrigated agriculture and recreation, as well as a diverse ecosystem. Large-quantity withdrawals from the source aquifer system have the potential to reduce the flow into the river and to adversely affect the free-flowing condition of the Niobrara National Scenic River (NSR). Therefore, to understand the magnitude and characteristics of those flows, the U.S. Geological Survey (USGS), in cooperation with the National Park Service, began a study to quantify seepage gains/losses along the eastern half of the Niobrara NSR and to create a map characterizing the base-flow recession time constant (tau) in the Niobrara NSR study area.

In 2016, a seepage study was completed to quantify seepage gains/losses along the eastern half of the Niobrara NSR. The seepage study results indicated that the main-stem streamflow on the Niobrara River increases 375 cubic feet per second $\left(\mathrm{ft}^{3} / \mathrm{s}\right)$ in the 39.9-mile study reach (river mile 119.3 to river mile 79.4). Although most of the streamflow increases are attributed to tributary inflows ( $297 \mathrm{ft}^{3} / \mathrm{s}, 79$ percent), $78 \mathrm{ft} 3 / \mathrm{s}$ are attributed to seepage gains within the reach. Seepage rates in the study reach ranged from 1.41 cubic feet per second per mile ([ft $3 / \mathrm{s}] / \mathrm{mi})$ to $2.56\left(\mathrm{ft}^{3} / \mathrm{s}\right) / \mathrm{mi}$, with a mean seepage rate of $2\left(\mathrm{ft}^{3} / \mathrm{s}\right) / \mathrm{mi}$.

Tau values were calculated at 10 sites in the Niobrara NSR study area, and kriging geostatistical techniques were used to develop a contour map to estimate tau values at locations where streamflow was not measured. The minimum tau value was 12.1 days at Willow Creek at Atwood Road near Carns, Nebraska (USGS station 06463670), and the maximum value was 45.5 days at Tyler Falls at Fort Niobrara National Wildlife Refuge near Valentine, Nebr. (USGS station 06461150).

\footnotetext{
${ }^{1}$ U.S. Geological Survey.
}

${ }^{2}$ Volunteer, U.S. Geological Survey.

\section{Introduction}

The Niobrara River of northern Nebraska (fig. 1) is a valuable water resource that sustains irrigated agriculture and recreation, as well as a diverse array of ecosystem types (Johnsgard, 2001). To protect this valuable water resource, a 76-mile reach from Borman Bridge near Valentine, Nebraska, to State Highway 137 near Mariaville, Nebr., was designated as the Niobrara National Scenic River (NSR) by the Niobrara Scenic River Designation Act of 1991 (16 U.S.C. 1274[a]). The falls, springs, and seeps along the Niobrara NSR are scenic and geologic features that have "outstandingly remarkable value" in relation to the river according to the National Wild and Scenic Rivers Act (Public Law 90-542; 16 U.S.C. 1271 et seq.) These features are a result of the intersection of the river valley with the High Plains aquifer system and are dependent on groundwater flow from that system. The tributary streams along the Niobrara NSR are cut into the aquifer, and their base flows also are likely derived primarily from groundwater inflows. Large-quantity withdrawals from the source aquifer system, such as for irrigation, have the potential to reduce the flow into the river from the aquifer and to adversely affect the outstandingly remarkable value and free-flowing condition of the Niobrara NSR. Therefore, to gain a better understanding of the magnitude and characteristics of those flows, the U.S. Geological Survey (USGS), in cooperation with the National Park Service, began a study to quantify seepage gains/losses along the eastern half of Niobrara NSR and to create a map characterizing the base-flow recession time constant (tau) in the Niobrara NSR Basin.

\section{Purpose and Scope}

The purpose of this report is to present results of the study to characterize the current magnitude and temporal variability of representative tributary inflows along the Niobrara NSR from 2016 to 2018. This report documents the data collection and analysis methods for the development of a map of tau, the quantification of stream seepage gains/losses along the eastern half of the Niobrara NSR, and the comparison of 


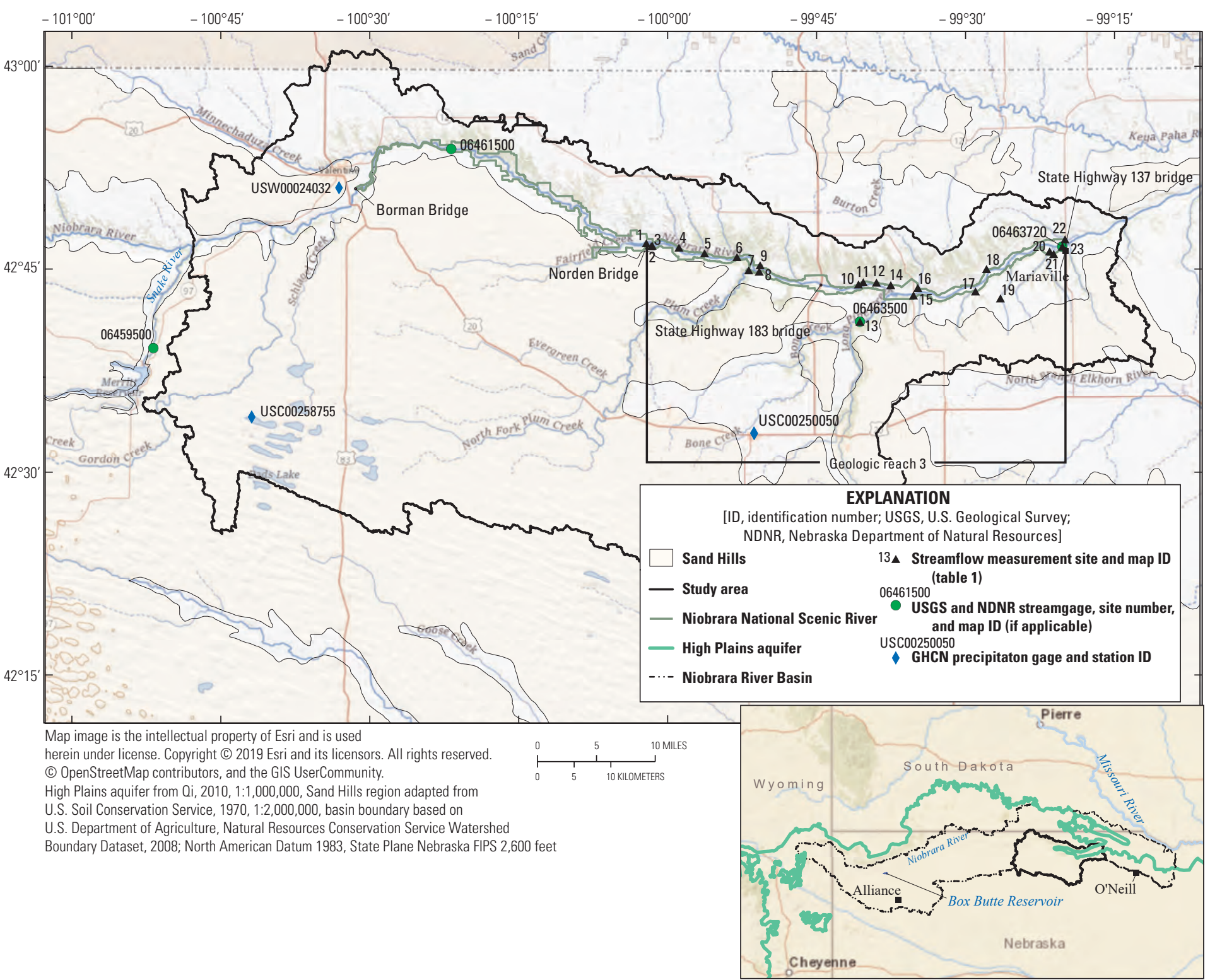

Figure 1. Locations of study area, U.S. Geological Survey and Nebraska Department of Natural Resources streamflow measurement sites, and Global Historical Climatology Network precipitation gages in the Niobrara River Basin. 
these values to previous studies. The geospatial datasets used in this study are available as a USGS data release (Strauch and Soenksen, 2022).

\section{Study Area Description}

The Niobrara River originates in east-central Wyoming and flows eastward about 560 miles before reaching its confluence with the Missouri River in northeast Nebraska. The total drainage area is about 13,480 square miles and includes parts of Wyoming and South Dakota, but most of the basin is within Nebraska (fig. 1; U.S. Department of Agriculture, Natural Resources Conservation Service, 2008). Annual precipitation increases gradually from 14 inches (in.) in the semiarid steppe of east-central Wyoming to 24 in. in the subhumid glacial-till terrain along the northeastern margin of Nebraska (Fenneman, 1928; Dugan and Zelt, 2000). The Niobrara River alternately flows through wide alluvial valleys, canyons, and valleys bounded by steep escarpments (University of NebraskaLincoln, Conservation and Survey Division, 1986; Alexander and others, 2009).

Much of the Niobrara River Basin overlies the High Plains aquifer, a massive aquifer system extending from South Dakota to Texas that is the source of water for much of the irrigated agriculture in the region (McGuire and Peterson, 2008). Additionally, a large part of the Niobrara River Basin lies in the Sand Hills, a vast region of vegetation-stabilized sand dunes that is part of the High Plains aquifer (Soller and Reheis, 2004). The high infiltration capacity of the Sand Hills almost completely eliminates direct surface runoff from precipitation, and the aquifer generally contributes substantial seepage, hereinafter called "base flow," to the surrounding rivers (Bentall and Shaffer, 1979). The dominance of a groundwater-affected streamflow regime in the Niobrara River is most evident west of Valentine, Nebr., where the Niobrara River flow is steady and persistent. East of Valentine, precipitation and storm-generated runoff progressively increase as a part of total streamflow (Shaffer, 1975; Soenksen and others, 1999).

The Niobrara River Basin is relatively undeveloped compared to other large river basins of Nebraska, and local economies are dependent on a combination of cattle ranching, agriculture, and recreation and tourism (Schultz, 2009).

Two large dams, Box Butte on the Niobrara River and Merritt on the Snake River, store surface water for large irrigation projects and affect the flow regime of the Niobrara River. Most of the irrigation wells in the basin are concentrated in two areas, one in the southwestern region near Alliance and one in the southeastern region near O'Neill (Alexander and others, 2009). The magnitude of effects from groundwater irrigation development on streamflow in the Niobrara River Basin has not been fully assessed.

Seepage studies completed in 1980 and 2009 by the Nebraska Department of Natural Resources and the USGS indicated that the Niobrara NSR main stem downstream from the Norden Bridge, was apparently losing flow to the underlying alluvial aquifer, although surface-water flow from tributaries along that reach offset those losses from the Niobrara River to the aquifer (Soenksen and others, 2010). To further quantify the extent of this finding along the eastern half of the Niobrara NSR, the methodology from Soenksen and others (2010) was repeated in 2016 for this study on a smaller (39.9-mile) reach of the river, termed geologic reach 3 , where the losses from the Niobrara River to the aquifer were most prevalent.

\section{Methods}

Two types of analysis were used to assess the base-flow conditions in the Niobrara NSR. First, a seepage study was completed in October 2016, and the data were analyzed to determine streamflow gain and loss locations, as well as rates and magnitudes of the gains and losses at the time of the study. Second, tau values were calculated and spatially mapped using kriging methods for data from July 1 to October 31, 2016-18.

\section{Main-Stem Seepage Conditions and Calculations}

The primary source of data for the seepage study consisted of streamflow measurements of the Niobrara River main stem and tributaries. USGS staff measured the main-stem streamflows, and USGS and National Park Service staff measured tributary streamflows.

\section{Base-Flow Conditions and Temporal Variability}

Under ideal base-flow conditions for seepage studies, increases in streamflow would steadily recede to base flow, which is the water that drains from the aquifer into the stream channel, until streamflow is affected by additional factors such as precipitation, snowmelt, evaporation, plant transpiration, or flow manipulation. If the maximum and minimum streamflows do not occur at the start and end of the day, respectively, baseflow conditions are not ideal. In such cases, the maximum and minimum flows within given days can indicate the temporal variability that contributes to potential error in determining the site-to-site differences in streamflow. Assuming no measurement error, if an upstream site were measured on the lower part of the range of within-site flow variability and the next downstream site were measured on the higher part of the range of within-site flow variability, the computed difference (downstream minus upstream) would positively bias the estimated gain or loss between the adjacent sites. The converse relations between adjacent streamflow measurements and the within-site range of temporal variability would negatively bias the estimated gain or loss from seepage. Where temporally 
continuous streamflow data were available, this temporal variability range was determined and reported as a source of potential error in the gain-loss calculations.

The hydrologic conditions leading up to and during the seepage study, October 26-27, 2016, are shown for three streamgages and the nearest National Oceanic and Atmospheric Administration Global Historical Climatology Network daily data precipitation station record (Menne and others, 2012a, b; U.S. Geological Survey, 2020) (figs. 1 and 2). Downstream from Merritt Reservoir, the Nebraska Department of Natural Resources streamgage, Snake River near Burge (station 06459500; Nebraska Department of Natural Resources, 2020), shows increasing flow beginning around October 13, 2016, before leveling off on October 21, 2016 (fig. 2). This increase in inflows from the tributary of the Niobrara River seems to increase streamflow upstream from the seepage study at the Niobrara River near Sparks, Nebr., streamgage (fig. 2; USGS station 06461500); however, the precipitation records indicate that as much as $0.5 \mathrm{in}$. of rain fell over much of the basin on October 19, 2016, which would also contribute to the increasing streamflows. At the easternmost measurement site in the seepage study, the Niobrara River at Mariaville, Nebr. (USGS station 06463720), streamgage record is incomplete because of equipment malfunctions from October 19 to October 24, 2016; however, the streamflow seemed to stabilize around October 25, 2016, and during the seepage study measurement period, October 26-27, 2016 (fig. 2). The continuous streamflow data shown were not available for all sites measured during the seepage study, but the data from these gaged sites can be used as a relative indicator of conditions for other sites along the main stem. Precipitation in northern Nebraska during early-to-middle October 2016 resulted in substantial increases in surface runoff to streams. Consequently, although the seepage study was scheduled for a period with expected base-flow conditions, actual conditions were not ideal because there was little time for surface runoff to exit the basin and high soil-moisture conditions likely existed on the lower part of the basin. In spite of these conditions, the seepage study measurements were completed during October 26-27, 2016.

\section{Streamflow Measurements and Estimated Uncertainty}

For the main-stem Niobrara River, streamflow measurements were made in a downstream direction to "follow the flow" and to minimize general recessional differences that could otherwise occur. For the main-stem Niobrara River streamflow measurement locations from Norden Bridge downstream to the State Highway 137 bridge, at least two successive streamflow measurements were completed at each site. To the extent possible, tributary measurements were made on the same day as the corresponding main-stem measurements. Site distribution was mainly determined by site access and landowner permissions. For the main-stem sites, site distribution was primarily dictated by the location of bridges. Streamflow measurements were made using standard methods of the USGS (Rantz and others, 1982; Nolan and Shields, 2000) as discussed in more detail in this section.

The gain-loss calculations were directly dependent on streamflow measurements; therefore, every reasonable effort was made to measure streamflow as precisely as practical, but measurement accuracy still varied based on individual site conditions. Streamflow measurements made in 2016 were assigned a subjective rating for measurement uncertainty in view of site conditions (Rantz and others, 1982); for example, a rating of "excellent" indicated that the measurement was considered to have a 2-percent uncertainty at the time of the measurement. Other ratings included "good," "fair," and "poor," indicating presumed measurement uncertainties of 5, 8 , or greater than 8 percent of the actual streamflow, respectively. The uncertainty ratings were based on the professional judgment of the hydrographer and incorporate consideration of a variety of environmental and hydraulic factors, including distribution of flow across the channel, channel geometry, channel hydraulic controls, and flow stability.

\section{Midsection and Point-Velocity Method}

Although several methods for measuring streamflow were used during the study, almost all measurements were made using the midsection method, with velocity measurements made at prescribed points in the vertical profile of the section. In this method, the stream cross section is divided into partial areas (subsections) for which the hydraulic area and and mean velocity are determined (Buchanan and Somers, 1969; Sauer and Turnipseed 2010; Turnipseed and Sauer 2010). The total streamflow is the summation of the products of area and mean velocity for all the subsections. Widths were determined from a graduated tape or tagline stretched across the measured section.

Water depths were measured directly using either a graduated wading rod or by sounding with a streamlined weight attached to a cable raised and lowered from a portable crane by a reel with an integral depth indicator (Buchanan and Somers, 1969; Rantz and others, 1982). A few measurements made by different methods are discussed in the "Acoustic Doppler Current Profiler and Other Methods" section. If water depth was too shallow to "zero" the depth indicator when the velocity meter (connected above the sounding weight) was centered on the water surface, depths were estimated.

Several combinations of equipment and methods were used to measure velocity. On the tributary streams, all measurements were made by wading with either Price verticalaxis meters (type AA or Pygmy) (Buchanan and Somers, 1969; Rantz and others, 1982) or SonTek FlowTracker acoustic Doppler velocimeters (ADVs) (Blanchard, 2007, 2009; Rehmel, 2007), which use the measured Doppler shift of an acoustic signal reflected off of particles in the water to determine velocity. For all streamflow measurements made from bridges on the Niobrara River main stem, velocities were 


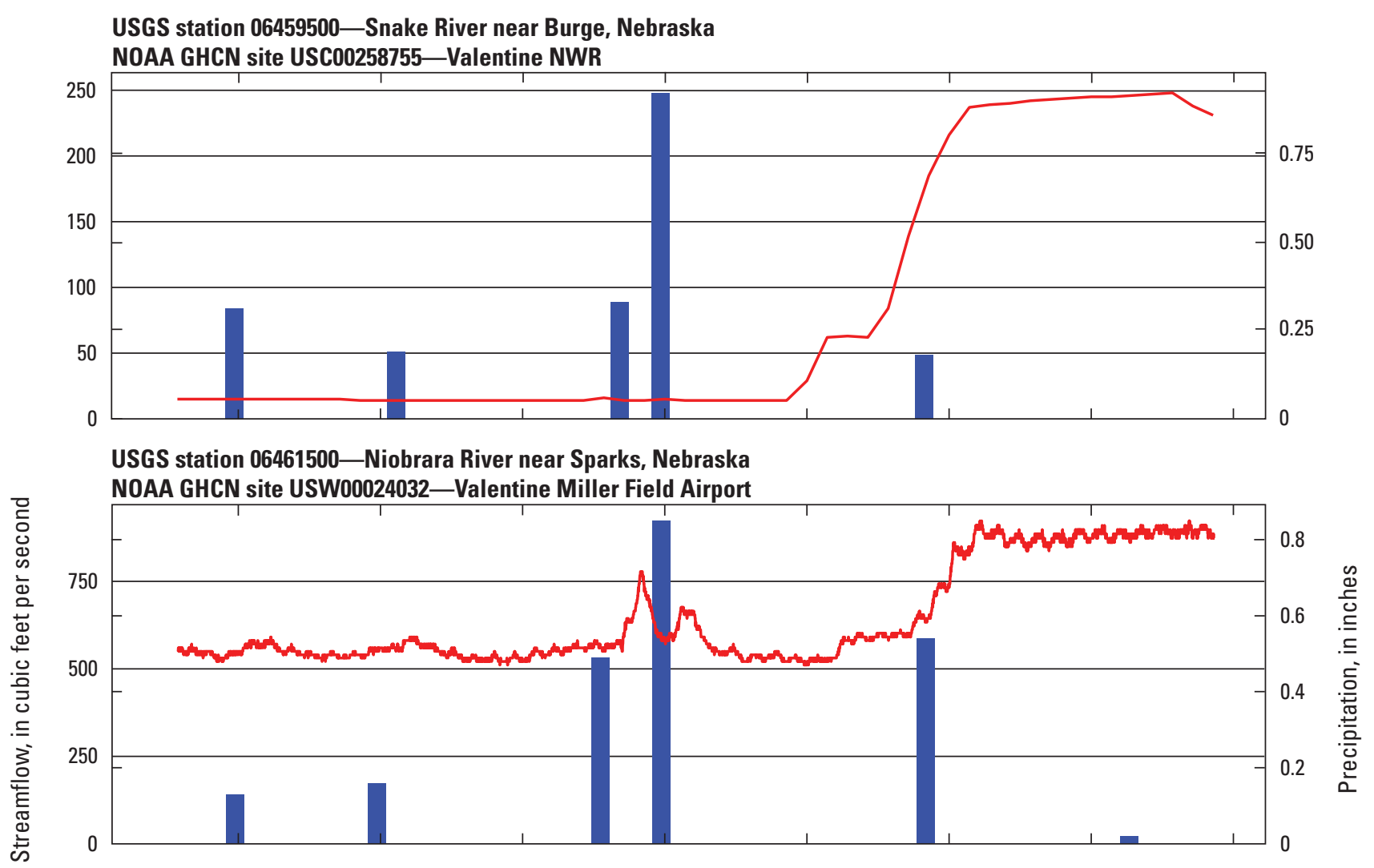

USGS station 06463720 - Niobrara River at Mariaville, Nebraska NOAA GHCN site USC00250050-Ainsworth

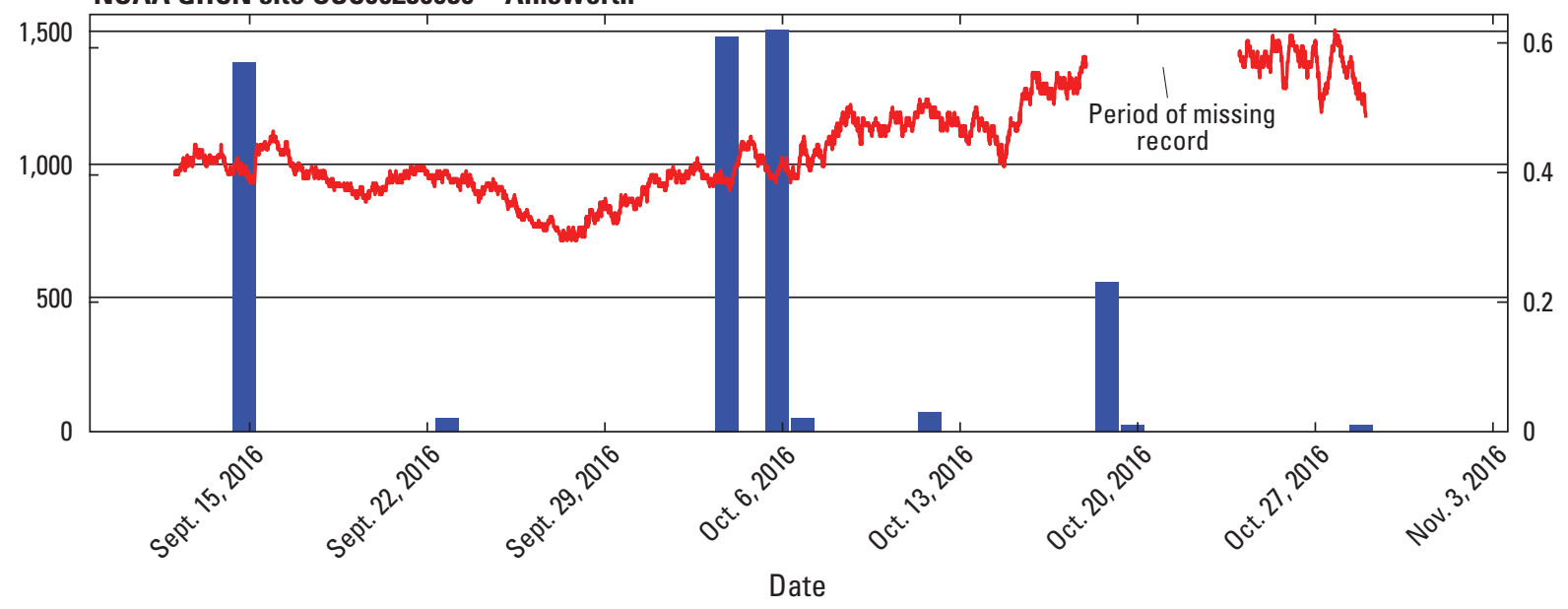

EXPLANATION

[USGS, U.S. Geological Survey; NOAA, National Oceanic and Atmospheric Administration; GHCN, Global Historical Climatology Network]

Total daily precipitation

Streamflow

Figure 2. Streamgage streamflow record and daily precipitation during 0ctober 1-31, 2016. Streamflow from U.S. Geological Survey (U.S. Geological Survey, 2020) and Nebraska Department of Natural Resources (Nebraska Department of Natural Resources, 2020); precipitation data from National Oceanic and Atmospheric Administration Global Historical Climatology Network (Menne and others, 2012a, b). 
measured using an RDI StreamPro ${ }^{\circledR}(2.0$ megahertz) acoustic Doppler current profiler (ADCP) (Teledyne RD Instruments, 2006). Standard USGS procedures were used to determine the depths in the water column where velocity measurements were made, which are dependent on the velocity meter being used and the depth of the flow at the section (Buchanan and Somers, 1969; Rantz and others, 1982; Blanchard, 2007, 2009; Rehmel, 2007). In cases where water depth was less than 2.5 times the distance from the center of the velocity meter to the bottom of the sounding weight, which occurred often at some sites, a velocity measurement was made as low in the vertical profile as possible and then adjusted on the basis of the typical vertical-velocity curve from Buchanan and Somers (1969) to estimate the mean velocity for the subsection. If water depth was too shallow to submerge the velocity meter into the flow, the velocity was estimated from the trends of adjacent subsections or from direct estimates at the subsection. At the interface of vertical obstructions (for example, piers), velocity was estimated from the adjacent section using the method from Rantz and others (1982, p. 82).

Beam checks of the ADV transducers are routinely made in the office, and electronic files of the results are archived as part of the normal quality-assurance procedures. A less extensive beam check was made in the field before each measurement and automatically recorded in the electronic measurement file. For Price AA meters, spin tests of the mechanical bucket wheels were made before and after the field study and between most measurements. The results were manually recorded on the measurement notes and in office log books.

\section{Acoustic Doppler Current Profiler and Other Methods}

The RDI StreamPro ${ }^{\circledR}(2.0$ megahertz) ADCP unit was used to make streamflow measurements using standard USGS procedures (Mueller and others, 2013). The ADCP was mounted under small portable boats that were tethered either from a bridge or from a line stretched across the stream, with a wireless communications link between the ADCP and a portable computer. Similar to the ADVs, the ADCPs use an acoustic signal to determine current velocity. In addition, ADCPs measure the depth and velocity throughout most of the vertical profile simultaneously while traversing the cross section. Standard procedure is to make several traverses in each direction until four consecutively measured streamflows are within 5 percent of each other. For one-person operation, the StreamPro was used in section-by-section mode, which is similar to the midsection and point-velocity method, but depth and velocity were measured using the ADCP. Because of simultaneous measurements of depth and the velocity profile, the StreamPro measurements took less time than the concurrent Price AA measurements.

At some tributary sites, where conditions were not favorable for streamflow measurement (for example, when flow was zero or minimal), streamflow was estimated based on the hydrographer's judgment. Such estimates were only made when flows were of small magnitude (less than or equal to 0.33 cubic foot per second $\left[\mathrm{ft}^{3} / \mathrm{s}\right]$ ). Knowledge of zero flow at a site is important, and such observations were documented.

\section{Gain/Loss Calculations and Levels of Uncertainty}

For the 2016 seepage study, calculations of streamflow gains or losses from aquifer seepage were made from the inflow and outflow terms of a volume balance approach; that is, by combination of measured main-stem and tributary streamflows. For any two sites along a given reach of stream, the stream inflows were summed (that is, upstream streamflow plus the streamflows of any inflowing tributaries), and the total was then subtracted from the outflowing streamflow at the downstream end of the reach. By assuming that (1) all tributary inflows were accounted for (measured or estimated), (2) the effects from temporal variability or measurement bias were negligible, and (3) change in storage was negligible, a positive difference would indicate a gain in streamflow from inflowing aquifer seepage and a negative difference would indicate a loss in streamflow through seepage outflow to the aquifer from the reach.

Linear-mean rates of gain or loss for total flow, tributary inflow, and aquifer seepage for the main stem were computed for each reach between measurement sites by dividing the gain or loss by the length of the reach. To evaluate the reliability of the gain/loss for a given reach, the computed seepage gain/loss was compared to the estimated combined magnitude of the two sources of uncertainty affecting measured streamflows; that is, potential temporal variability and measurement uncertainty related to site conditions. Both sources of uncertainty affect the calculated gain/loss more where measured sites are close together and the magnitude of gain/loss is small compared to the combined uncertainty.

To aid in comparability of results between 1980 and 2009 seepage studies, this study used the same reach breakpoints as described below; however, the extent of this study was limited to verifying the findings of the loss of flow in "geologic reach 3" in the 2009 study and quantifying the seepage gain/ loss to help inform future management of the river (Soenksen and others, 2010). In a downstream direction, the breakpoints for geologic reach 3 were Norden Bridge and State Highway 137 bridge. Geologic reach 3 is characterized by an abruptly thicker and wider unconsolidated alluvial aquifer (Burchett, 1986; Soenksen and others, 2010).

Uncertainty bars were computed for the main-stem streamflow measurements based on the subjective uncertainty ratings of each measurement (see "Streamflow Measurements and Estimated Uncertainty" section). For illustrative purposes only, uncertainty bars for measurements with conditions rated "poor" were arbitrarily set to 16 percent.

Cumulative tributary inflow, main-stem seepage, and total flow were computed in relation to distance along the channel in a downstream direction. For tributary inflows, this was a step increase along the main stem at the river mile of each contributing tributary confluence with the main stem. For 
main-stem seepage, the cumulative total changed gradually between each main-stem measurement site as the calculated gain or loss was prorated along the channel length between sites. The reconstructed total flow was the sum of the other two cumulative totals.

Error bands were then computed for the cumulative gain/ loss totals using the measurement uncertainty bars. The high band was computed by subtracting the low-uncertainty-bar value of the measured streamflow for the upstream site from the high-uncertainty-bar value of the measured streamflow for the downstream site of each reach. Conversely, the low uncertainty band was computed by subtracting the highuncertainty-bar streamflow for the upstream site from the lowuncertainty-bar streamflow for the downstream site for each reach. Similarly, uncertainty bands were computed for the main-stem seepage rates in the geologic reach. The uncertainty bars and bands reflect the subjective ratings of measurement uncertainty only and do not include the possible effects from temporal variability in streamflow.

\section{Base-Flow Recession Time Constants Calculation and Kriged Map Creation}

The base-flow recession time constant (tau) is a hydrologic index that characterizes the ability of a groundwater system to supply flow as seepage to a stream (Eng and Milly, 2007). Tau and other correlated hydrologic indices have been used as explanatory variables to greatly improve the predictive power of low-flow regression equations. The value of tau at streamflow sites indicates the dependence of total streamflow on groundwater inflow to the channel (Curran and others, 2012). The magnitude of tau indicates the degree of hydraulic conductivity of the stream to the groundwater system (Curran and others, 2012). Larger tau values indicate a stronger dependence on the groundwater system for streamflows; a smaller tau value indicates that the stream is not as dependent on the groundwater system (Curran and others, 2012) for streamflows. Tau $(\tau)$, is expressed as

$$
\tau=\Delta t / \ln \left(Q_{t} / Q_{t+\Delta t}\right),
$$

where

$$
\begin{aligned}
\tau & \text { is the base-flow recession time constant } \\
& \text { (in days), } \\
\Delta t & \text { is the time between observations (in days), } \\
Q_{t} & \text { is the streamflow at time } t, \text { and } \\
Q_{t+\Delta t} & \text { is the streamflow at time } t+\Delta t .
\end{aligned}
$$

The value of tau can be readily estimated from two measurements of streamflow during the same low-flow period without intervening storms (Eng and Milly, 2007); however, such estimates of tau at partial-record sites may have substantial error because of the small number of observations and may reflect inherent seasonality effects (for example, evapotranspiration) in some base-flow recessions (Brutsaert and Nieber, 1977). Because only three continuous streamgages in the Niobrara NSR were in operation during the study, the initial study design was to use the method of paired streamflow measurements to calculate tau at several locations in the basin and then correlate these values to tau values calculated at three index gages installed in the basin as part of the study. These correlations could be used to develop partial-record sites at the paired measurement sites. Because of the remote location of the study area, difficulties in timing of precipitation occurring during expected recession measurement timeframes, and increased uncertainty observed in the tau values collected by the paired measurement method, a modified method to obtain more tau values in the basin was implemented. In place of the paired measurement method, temporary streamgages were installed and operated to collect data over a longer period to be more likely to capture low-flow periods for which tau could be calculated. These temporary streamgages combined with the installed index gages for the study, and the three longterm (10 years or more) continuous streamgages, were used to calculate tau values from daily mean streamflow records for the concurrent years of 2016-18 or when streamflow data were available at the site during those years (U.S. Geological Survey, 2020). Tau values are seasonally dependent because they are derived from streamflow records for recession periods that are affected by evapotranspiration (Brutsaert, 1982, 2005; Zecharias and Brutsaert, 1988); therefore, tau value calculations were limited to the months of July-October because low-flow streamflow values generally occur at this time of year in the study area. At sites where more than one tau value was calculated, the mean of the values was used in analysis. In all, tau values were calculated for 10 sites in the Niobrara NSR study area.

The calculated tau values were then used to create a kriged map. Kriging is a geostatistical method that uses distance and variation of known measurements at sampled locations (streamgages) for the estimation of values at unsampled locations (ungaged sites) (Paramasivam and Venkatramanan, 2019). The kriged tau map could be used (1) as the basis for identifying areas with different hydrologic responsiveness, with differing potential to demonstrate the effects of management changes, and (2) in the development of regional low-flow regression equations (Eash and Barnes, 2017). The Geostatistical Analyst tools in ArcGIS Pro, version 2.5.2 (Esri, 2001), were used to create the kriged tau map and complete cross validation of the maps to determine the root mean square error of the tau map.

\section{Main-Stem Seepage}

Measurements or estimates of streamflow for 23 sites in the Niobrara River Basin geologic reach 3 (Norden Bridge to State Highway 137 bridge) were collected for the Niobrara NSR seepage study. An estimate of streamflow was made at 1 tributary site, and streamflow measurements were made at 
4 Niobrara main-stem and 18 tributary locations within the reach (table 1, fig. 1). All measurements were used in the streamflow gain/loss calculations.

Results from the 2016 seepage study are shown in figure 3 and summarized in table 2 . The 2016 seepage study indicates main-stem streamflow increases $375 \mathrm{ft}^{3} / \mathrm{s}$ from $1,050 \mathrm{ft}^{3} / \mathrm{s}$ at the beginning of the study reach (river mile 119.31) to $1,400 \mathrm{ft}^{3} / \mathrm{s}$ at the end of the reach (river mile 79.4) (fig. 3, table 1). Although most of the streamflow increases are attributed to tributary inflows $\left(297 \mathrm{ft}^{3} / \mathrm{s}, 79\right.$ percent), $78 \mathrm{ft}^{3} / \mathrm{s}$ are attributed seepage gains within the reach. Seepage rates in the study reach ranged from $1.41\left(\mathrm{ft}^{3} / \mathrm{s}\right) /$ mi (river miles $94.45-108.46)$ to $2.56\left(\mathrm{ft}^{3} / \mathrm{s}\right) / \mathrm{mi}$ (river miles 108.46-119.31), with a mean seepage rate of $2\left(\mathrm{ft}^{3} / \mathrm{s}\right) / \mathrm{mi}$.

When comparing the 2016 mean streamflow gain or loss rates to the previous studies, tributary inflow gains of $7.4\left(\mathrm{ft}^{3} / \mathrm{s}\right) / \mathrm{mi}$ are similar to the reported values for the 1980 and 2009 studies of 7.5 and $8.6\left(\mathrm{ft}^{3} / \mathrm{s}\right) / \mathrm{mi}$, respectively (table 2). Total main-stem mean rates for the 2016 study indicated gains of $9.4\left(\mathrm{ft}^{3} / \mathrm{s}\right) / \mathrm{mi}$ and were higher than that of the 1980 and 2009 values of 2 and $6.4\left(\mathrm{ft}^{3} / \mathrm{s}\right) / \mathrm{mi}$, respectively; however, this value continued an upward trend in the total main-stem mean rates from the previous studies. Main-stem mean seepage rates from the 2016 study indicate the Niobrara River is gaining flow from the groundwater at a mean rate of $2\left(\mathrm{ft}^{3} / \mathrm{s}\right) / \mathrm{mi}$. This value is in contrast to the 1980 and 2009 studies that determined the Niobrara River losing streamflow at rates of -5.5 and $-2.3\left(\mathrm{ft}^{3} / \mathrm{s}\right) / \mathrm{mi}$, respectively, within geological reach 3. Although the 2016 calculated mean gain/ loss rate values are in some cases different from the previous studies, it is important to note that all values are within the measurement uncertainty bounds for those previous studies. Some variances in the mean gain/loss rates could be attributed to antecedent precipitation in the basin at the time of the studies and temporal variation in the timing of the studies; that is, the 1980 study was completed in the spring and the 2009 and 2016 studies were completed in the fall. All three studies had similar total rainfall amounts for the 30 days before the study measurement periods (1980, 1.74 in.; 2009, 1.37 in.; 2016, 1.52 in.); however, the 1980 and 2009 studies had a minimum of 10 days without recorded precipitation before the study began, whereas the 2016 study only had 6 days (Menne and others, 2012a, b).

\section{Base-Flow Recession Time Constants}

Tau values were calculated at a total of 10 sites in the Niobrara NSR study area for July 1-October 31, 2016-18 (table 3, fig. 4). Calculated tau values at the streamgage locations had a mean value of 21.9 days and a median of 18.4 days in the study area. The minimum tau value was 12.1 days at Willow Creek at Atwood Road near Carns, Nebr. (USGS station 06463670; map ID 25), and the maximum tau value was 45.5 days at Tyler Falls at Fort Niobrara National Wildlife Refuge near Valentine, Nebr. (USGS station 06461150; map ID 28). Generally, tau values were smaller in the southeastern part of the study area and increased in magnitude in the north and northwest directions. The measurements are generally well distributed spatially; however, there is a gap in the southwestern part of the study area where equipment malfunctions at two sites during the streamflow data collection period prevented tau values from being calculated for those streamflow locations. Because of the spatial correlation in the tau values, kriging geostatistical techniques that account for directional bias were used to develop an interpolated map. Several kriging semivariogram models were tested for best fit and cross-validation estimation accuracy. The final model used simple kriging, with a spherical semivariogram, with a directional trend applied because of the anisotropy in the tau values. Contour maps of tau were then developed from the model output from the kriging process that can be used to estimate tau values at locations where streamflow was not measured (fig. 4) (Strauch and Soenksen, 2022). Estimated tau values from contour maps are commonly used as explanatory variables to greatly improve the predictive power of low-flow regression equations for estimating low-flow statistics; calibration of, or input to, rainfall-runoff models; hydrograph analysis for graphical separation of different flow components; and low-flow forecasting to benefit the management of irrigation, water supply, hydroelectric powerplants and waste dilution (Tallaksen, 1995). The contours of tau ranged from 21.0 to 25.3 days, generally increasing from southeast of the study area to the northwest. This directional variation in tau reinforces that most streamflows in the eastern part of the study area are more runoff dominated whereas streamflow in the western part is more base-flow dominated; that is, dependent on the underlying groundwater system. Cross validation of the map of tau values (fig. 4) calculated a root mean square error of 9.08 days. In some areas, the estimated contour values match the calculated tau values well; in other areas, there are substantial differences between the two values. These differences are in part because of the kriging interpolation methodology itself and the spatial distribution and quantity of the observed values. As with most interpolation methods, kriging interpolation prediction accuracy improves with more data points; to improve the accuracy of the kriging process, more calculated tau values would be needed, especially in the southwestern part of the study area where tau values were sparse. 
Table 1. Streamflow for selected Niobrara River main-stem and tributary sites from Norden Bridge near Norden, Nebraska, to State Highway 137 bridge at Mariaville, Nebr., during a seepage study, October 27-28, 2016.

[Streamflow measurement data are from U.S. Geological Survey (2020). ID, identification number; USGS, U.S. Geological Survey; ft³/s, cubic foot per second; MU, measurement uncertainty; \%, percent; Nebr., Nebraska; ADCP, acoustic Doppler current profiler; ADV, acoustic Doppler velocimeter; --, not assigned or no data]

\begin{tabular}{|c|c|c|c|c|c|c|c|c|c|}
\hline $\begin{array}{l}\text { Map ID } \\
\text { (fig. 1) }\end{array}$ & $\begin{array}{l}\text { USGS station } \\
\text { number }\end{array}$ & Stream or site name & $\begin{array}{l}\text { Latitude north } \\
\text { (degrees) }\end{array}$ & $\begin{array}{l}\text { Longitude } \\
\text { west } \\
\text { (degrees) }\end{array}$ & $\begin{array}{l}\text { River miles } \\
\text { upstream } \\
\text { from mouth }\end{array}$ & $\begin{array}{c}\text { Day of } \\
\text { month, } \\
\text { October } 2016\end{array}$ & $\begin{array}{c}\text { Streamflow } \\
\left(\mathrm{ft}^{3} / \mathrm{s}\right)\end{array}$ & $\begin{array}{l}\text { MU } \\
(\%)\end{array}$ & Meter type \\
\hline 1 & 06462000 & $\begin{array}{l}\text { Niobrara River near Norden, } \\
\text { Nebr. }^{2}\end{array}$ & 42.78695 & -100.035 & 119.3 & 27 & 1,050 & 6.5 & StreamPro ADCP \\
\hline 2 & 424659100013801 & $\begin{array}{l}\text { West Branch Niobrara River } \\
\text { tributary at Niobrara Valley } \\
\text { Preserve Ranch near Norden, } \\
\text { Nebr. }{ }^{3}\end{array}$ & 42.78306 & -100.027 & 118.7 & 27 & 0.69 & 10 & Price Pygmy \\
\hline 3 & 424700100013301 & $\begin{array}{l}\text { East Branch Niobrara River } \\
\text { tributary at Niobrara Valley } \\
\text { Preserve Ranch near Norden, } \\
\text { Nebr. }^{3}\end{array}$ & 42.78333 & -100.026 & 118.7 & 27 & 0.44 & 10 & Price Pygmy \\
\hline 4 & 424654099585001 & $\begin{array}{l}\text { Turkey Creek at River Road near } \\
\text { Meadville, Nebr. }{ }^{3}\end{array}$ & 42.78167 & -99.9806 & 116.4 & 27 & 2.7 & 10 & Price Pygmy \\
\hline 5 & 424627099561601 & $\begin{array}{l}\text { Chimney Creek at River Road } \\
\text { near Meadville, Nebr. }{ }^{3}\end{array}$ & 42.77417 & -99.9378 & 113.9 & 27 & 1.1 & 10 & Price Pygmy \\
\hline 6 & 424611099530201 & $\begin{array}{l}\text { Cub Creek at River Road near } \\
\text { Meadville, Nebr. }{ }^{3}\end{array}$ & 42.76972 & -99.8839 & 110.9 & 27 & 2.3 & 10 & Price Pygmy \\
\hline 7 & 06462500 & Plum Creek at Meadville, Nebr. ${ }^{3}$ & 42.75361 & -99.864 & 108.6 & 27 & 120 & 8 & FlowTracker ADV \\
\hline 8 & 06463000 & $\begin{array}{l}\text { Niobrara River at Meadville } \\
\text { Nebr. }^{2}\end{array}$ & 42.75139 & -99.8462 & 108.5 & 27 & 1,200 & 8 & StreamPro ADCP \\
\hline 9 & 424534099504201 & $\begin{array}{l}\text { Rock Creek at Meadville Road at } \\
\text { Meadville, Nebr. }{ }^{3}\end{array}$ & 42.75944 & -99.845 & 108 & 27 & 2.7 & 10 & Price Pygmy \\
\hline 10 & 424408099405201 & $\begin{array}{l}\text { Thomas Creek at Riverview } \\
\text { Road near Riverview, Nebr. }{ }^{3}\end{array}$ & 42.73556 & -99.6811 & 99.1 & 27 & 0.70 & -- & estimate \\
\hline 11 & 424418099402401 & $\begin{array}{l}\text { Luckey Creek at Riverview Road } \\
\text { near Riverview, Nebr. }{ }^{3}\end{array}$ & 42.73833 & -99.6733 & 98.9 & 27 & 0.25 & 10 & FlowTracker ADV \\
\hline 12 & 424415099390301 & $\begin{array}{l}\text { Rickman Creek at Riverview } \\
\text { Road near Riverview, Nebr. }\end{array}$ & 42.7375 & -99.6508 & 97.8 & 27 & 0.56 & 10 & FlowTracker ADV \\
\hline 13 & 06463500 & $\begin{array}{l}\text { Long Pine Creek near Riverview, } \\
\text { Nebr. }{ }^{3}\end{array}$ & 42.68944 & -99.6789 & 96.6 & 27 & 150 & 5 & FlowTracker ADV \\
\hline 14 & 424404099373701 & $\begin{array}{l}\text { Beeman Creek at Riverview } \\
\text { Road near Riverview, Nebr. }{ }^{3}\end{array}$ & 42.73444 & -99.6269 & 96.6 & 27 & 1.0 & 10 & Price Pygmy \\
\hline 15 & 424318099352101 & $\begin{array}{l}\text { Niobrara River at Highway } 7 \text { at } \\
\text { Riverview, Nebr. }{ }^{2}\end{array}$ & 42.72169 & -99.5892 & 94.4 & 27 & 1,400 & 8 & StreamPro ADCP \\
\hline
\end{tabular}


Table 1. Streamflow for selected Niobrara River main-stem and tributary sites from Norden Bridge near Norden, Nebraska, to State Highway 137 bridge at Mariaville, Nebr., during a seepage study, October 27-28, 2016.-Continued

[Streamflow measurement data are from U.S. Geological Survey (2020). ID, identification number; USGS, U.S. Geological Survey; ft³/s, cubic foot per second; MU, measurement uncertainty; \%, percent; Nebr., Nebraska; ADCP, acoustic Doppler current profiler; ADV, acoustic Doppler velocimeter; --, not assigned or no data]

\begin{tabular}{|c|c|c|c|c|c|c|c|c|c|}
\hline $\begin{array}{l}\text { Map ID } \\
\text { (fig. 1) }\end{array}$ & $\begin{array}{l}\text { USGS station } \\
\text { number }\end{array}$ & Stream or site name & $\begin{array}{l}\text { Latitude north } \\
\text { (degrees) }\end{array}$ & $\begin{array}{c}\text { Longitude } \\
\text { west } \\
\text { (degrees) }\end{array}$ & $\begin{array}{c}\text { River miles } \\
\text { upstream } \\
\text { from mouth }{ }^{1}\end{array}$ & $\begin{array}{c}\text { Day of } \\
\text { month, } \\
\text { October } 2016\end{array}$ & $\begin{array}{l}\text { Streamflow } \\
\quad\left(\mathrm{ft}^{3} / \mathbf{s}\right)\end{array}$ & $\begin{array}{l}\text { MU } \\
(\%)\end{array}$ & Meter type \\
\hline 16 & 424349099344601 & $\begin{array}{l}\text { Wyman Creek at Riverview } \\
\text { Road at Riverview, Nebr. }\end{array}$ & 42.73028 & -99.5794 & 93.9 & 27 & 1.8 & 10 & Price Pygmy \\
\hline 17 & 424334099290801 & $\begin{array}{c}\text { Laughing Water Creek at Carns } \\
\text { Avenue near Carns, Nebr. }{ }^{3}\end{array}$ & 42.72611 & -99.4856 & 88.8 & 27 & 3.2 & 10 & Price Pygmy \\
\hline 18 & 424513099280101 & $\begin{array}{l}\text { East Hall Creek } 1.5 \text { miles north- } \\
\text { east of Carns, Nebr. }{ }^{3}\end{array}$ & 42.75361 & -99.4669 & 86.8 & 27 & 0.83 & 10 & Price Pygmy \\
\hline 19 & 424302099263901 & $\begin{array}{l}\text { Rock Creek at Atwood Road } \\
\text { near Carns, Nebr. }{ }^{3}\end{array}$ & 42.71722 & -99.4442 & 85 & 28 & 4.4 & 5 & Price Pygmy \\
\hline 20 & 424629099214101 & $\begin{array}{l}\text { Willow Creek at Antelope Road } \\
\text { near Mariaville, Nebr. }{ }^{3}\end{array}$ & 42.77472 & -99.3614 & 80.5 & 27 & 0.67 & 8 & Price Pygmy \\
\hline 21 & 424618099211801 & $\begin{array}{l}\text { Oak Creek at Antelope Road } \\
\text { near Mariaville, Nebr. }{ }^{3}\end{array}$ & 42.77167 & -99.355 & 79.8 & 28 & 2.7 & 5 & Price Pygmy \\
\hline 22 & 424722099200801 & $\begin{array}{l}\text { Big Anne Creek at Old Highway } \\
137 \text { at Mariaville, Nebr. }{ }^{3}\end{array}$ & 42.78944 & -99.3356 & 79.4 & 28 & 1.0 & 8 & Price Pygmy \\
\hline 23 & 06463720 & $\begin{array}{l}\text { Niobrara River at Mariaville, } \\
\text { Nebr. }^{2}\end{array}$ & 42.78056 & -99.3397 & 79.4 & 27 & 1,400 & 6.5 & StreamPro ADCP \\
\hline
\end{tabular}

${ }^{1}$ River miles are given for the confluence of tributaries with the Niobrara River and used in gain/loss computations. The value represents the distance to the confluence from the mouth of Niobrara River. ${ }^{2}$ Streamflow is the mean of two concurrent measurements made at the site.

${ }^{3}$ Denotes tributary stream or site. 


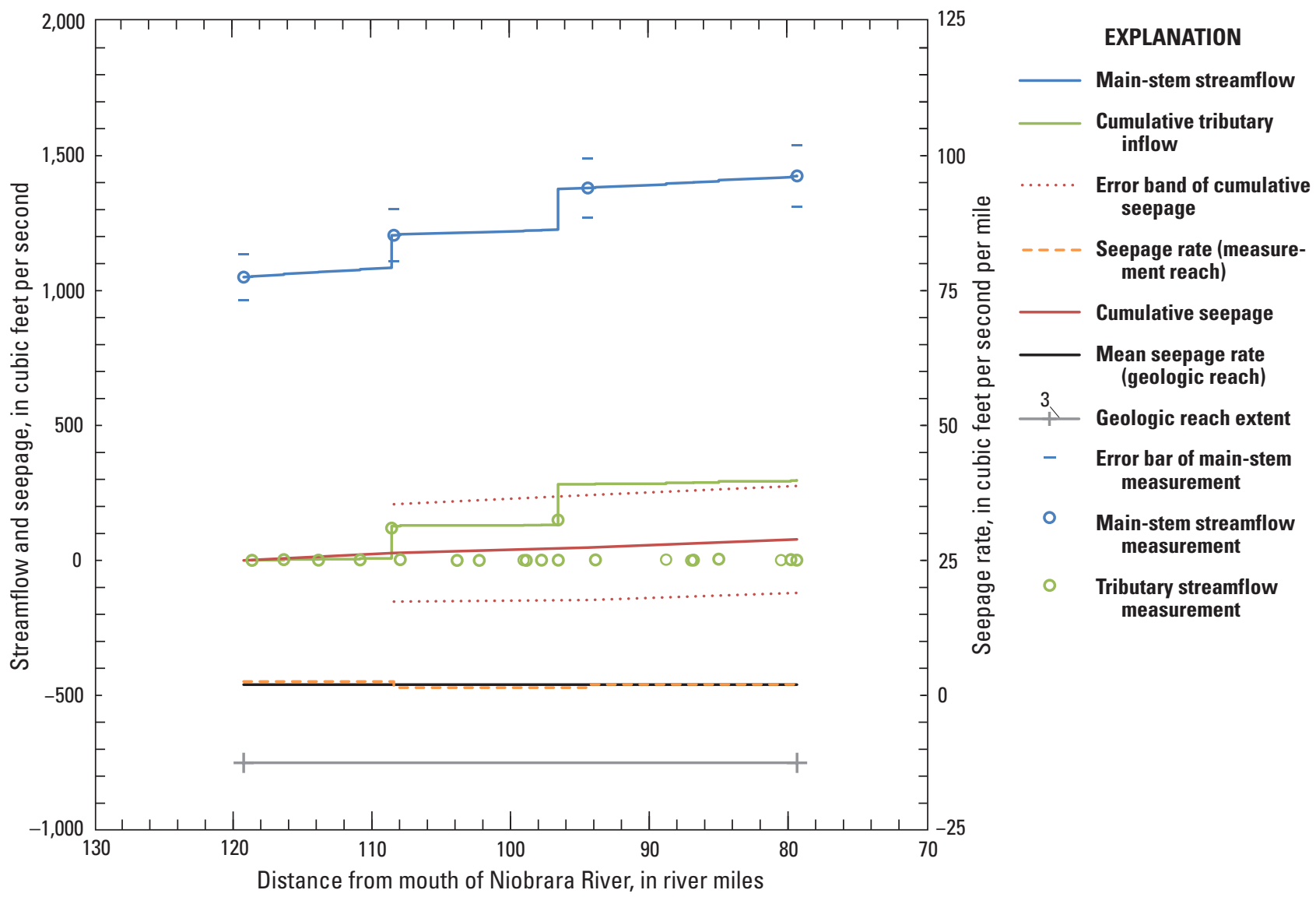

Figure 3. Niobrara River streamflow along the geologic reach from Norden Bridge (fig. 1, map identification number [ID] 1) to Meadville (fig. 1, map ID 8) to State Highway 7 (fig. 1, map ID 15) to State Highway 137 bridge (fig. 1, map ID 23), as reconstructed from main-stem and tributary inflow measurements, computed main-stem seepage gains/losses, and computed seepage gain/loss rates during the base-flow seepage study, October 27-28, 2016. 
Table 2. Mean rates of streamflow gain or loss in the main stem summarized for total flow, tributary inflows, and main-stem seepage, with the interval of uncertainty, for geologic reach 3 of Niobrara River, April 21-30, 1980; November 9-13, 2009; and October 27-28, 2016.

[Map IDs (identification numbers) are shown in figure 1; river miles are the curvilinear distance from the river mouth; computed rates are listed in bold; (fts/s)/mi, cubic foot per second per mile; --, no data or not computed]

\begin{tabular}{|c|c|c|c|c|c|c|c|c|c|c|}
\hline \multirow[t]{2}{*}{ Geologic reach along Niobrara River } & \multirow[t]{2}{*}{ Calculation type } & \multicolumn{3}{|c|}{$\begin{array}{c}\text { Total main-stem gain/ } \\
\text { loss of flow, mean rate } \\
\left(\left[\mathrm{ft}^{3} / \mathrm{s}\right] / \mathrm{mi}\right)\end{array}$} & \multicolumn{3}{|c|}{$\begin{array}{c}\text { Tributary inflows, reach } \\
\text { total, mean rate } \\
\left(\left[\mathrm{ft}^{3} / \mathrm{s}\right] / \mathrm{mi}\right)\end{array}$} & \multicolumn{3}{|c|}{$\begin{array}{c}\text { Main-stem gain/loss from } \\
\text { seepage, mean rate } \\
\left(\left[\mathrm{ft}^{3} / \mathrm{s}\right] / \mathrm{mi}\right)\end{array}$} \\
\hline & & 1980 & 2009 & 2016 & 1980 & 2009 & 2016 & 1980 & 2009 & 2016 \\
\hline \multirow{3}{*}{$\begin{array}{l}\text { Norden Bridge (map ID 1) to State Highway } 137 \text { bridge (map ID 23) } \\
\quad \text { (river mile } 119.3 \text { to } 79.4 \text {, geologic reach } 3 \text { ) }\end{array}$} & Upper uncertainty limit & 10.6 & 10.3 & 14.3 & -- & -- & -- & 3.1 & 1.7 & 6.9 \\
\hline & Computed rates & 2 & 6.4 & 9.4 & 7.5 & 8.6 & 7.4 & -5.5 & -2.3 & 2 \\
\hline & Lower uncertainty limit & -6.7 & 2.4 & 4.4 & -- & -- & -- & -14.2 & -6.2 & -3 \\
\hline
\end{tabular}


Table 3. Calculated tau values at streamgage locations in the Niobrara National Scenic River study area, July 1-0ctober 31, 2016-18.

[Streamflow data and the period of record are from U.S. Geological Survey (2020); ID, identification number; USGS, U.S. Geological Survey; tau, base-flow recession time constant; stnd dev, standard deviation; Nebr., Nebraska; present, 2021; --, insufficient data to do the calculation]

\begin{tabular}{|c|c|c|c|c|c|c|c|c|}
\hline $\begin{array}{l}\text { Map ID } \\
\text { (fig. 4) }\end{array}$ & USGS station number & Site name & $\begin{array}{c}\text { Latitude } \\
\text { north } \\
\text { (degrees) }\end{array}$ & $\begin{array}{l}\text { Longitude } \\
\text { west } \\
\text { (degrees) }\end{array}$ & Period of record & $\begin{array}{l}\text { Tau mean } \\
\text { (days) }\end{array}$ & $\begin{array}{l}\text { Tau } \\
\text { count }\end{array}$ & $\begin{array}{c}\text { Tau stnd } \\
\text { dev } \\
\text { (days) }\end{array}$ \\
\hline 24 & 06461595 & $\begin{array}{l}\text { East Middle Creek at Norden Road near Norden, } \\
\text { Nebr. }\end{array}$ & 42.79417 & -100.055 & $11 / 20 / 2015-07 / 11 / 2018$ & 18.9 & 9 & 3.6 \\
\hline 25 & 06463670 & Willow Creek at Atwood Road near Carns, Nebr. & 42.71722 & -99.41472 & 09/30/2015-10/01/2018 & 12.1 & 9 & 2 \\
\hline 26 & 423552100085501 & $\begin{array}{l}\text { Cedar Creek at U.S. Highway } 20 \text { near } \\
\text { Johnstown, Nebr. }\end{array}$ & 42.59778 & -100.1486 & 07/13/2018-10/02/2018 & 16.4 & 2 & 0.51 \\
\hline 27 & 423754099522201 & $\begin{array}{l}\text { Sand Draw at 430th Avenue near Ainsworth, } \\
\text { Nebr. }\end{array}$ & 42.63167 & -99.87278 & 07/11/2018-10/01/2018 & 16.2 & 2 & 1 \\
\hline 28 & 06461150 & $\begin{array}{l}\text { Tyler Falls at Fort Niobrara National Wildlife } \\
\text { Refuge near Valentine, Nebr. }\end{array}$ & 42.90361 & -100.4258 & $11 / 21 / 2015-10 / 02 / 2018$ & 45.5 & 2 & 0.01 \\
\hline 29 & 06461500 & Niobrara River near Sparks, Nebr. & 42.90222 & -100.3622 & 10/01/1945-present & 31.3 & 13 & 8.8 \\
\hline 13 & 06463500 & Long Pine Creek near Riverview, Nebr. & 42.68944 & -99.67889 & 05/01/1948-present & 24.7 & 6 & 3.5 \\
\hline 23 & 06463720 & Niobrara River at Mariaville, Nebr. & 42.78056 & -99.33972 & 05/21/2012-present & 20.8 & 10 & 6.7 \\
\hline 30 & 423323099520101 & Bone Creek at Wilson Street at Ainsworth, Nebr. & 42.55639 & -99.86694 & $07 / 12 / 2018-08 / 27 / 2018$ & 15.6 & 1 & -- \\
\hline 31 & 425250100334501 & $\begin{array}{l}\text { Minnechaduza Creek at U.S. Highway } 83 \text { at } \\
\text { Valentine, Nebr. }\end{array}$ & 42.88056 & -100.5625 & 08/29/2018-10/02/2018 & 17.8 & 2.0 & 0.4 \\
\hline
\end{tabular}




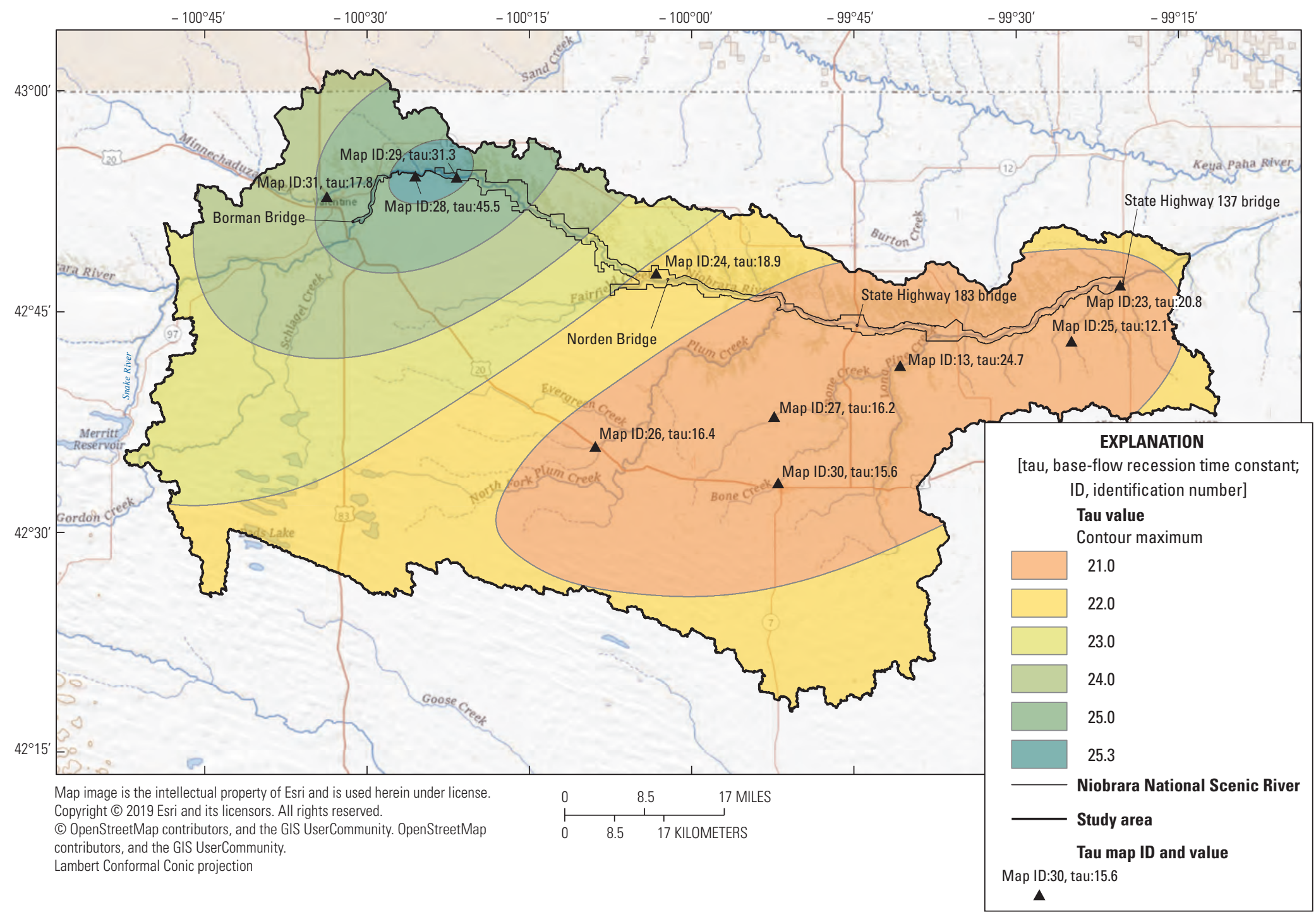

Figure 4. Location of calculated tau values and map of filled tau contours for sites in the Niobrara National Scenic River study area, July 1-0ctober 31, 2016-18. 


\section{Summary}

The Niobrara River of northern Nebraska is a valuable water resource that sustains irrigated agriculture and recreation, as well as a diverse array of ecosystem types. To protect this valuable water resource, a 76-mile reach from Borman Bridge near Valentine to State Highway 137 near Mariaville was designated as the Niobrara National Scenic River (NSR) by the Niobrara Scenic River Designation Act of 1991. The falls, springs, and seeps along the Niobrara National Scenic River (NSR) are scenic, and geologic features that are a result of the river valley's intersection with the High Plains aquifer system and are dependent on groundwater flow from that system. Large-quantity withdrawals from the source aquifer system, such as for irrigation, have the potential to reduce the flow into the river from the aquifer and to adversely affect the free-flowing condition of the Niobrara NSR. Therefore, to gain a better understanding of the magnitude and characteristics of those flows, the U.S. Geological Survey (USGS), in cooperation with the National Park Service, began a study to quantify seepage gains/losses along the eastern half of the Niobrara NSR and to create a map characterizing the base-flow recession time constant (tau) in the Niobrara NSR study area.

To quantify seepage gains/losses along the eastern half of the main-stem Niobrara River, measurements or estimates of streamflow for 23 sites in the Niobrara River Basin geologic reach 3 (Norden Bridge to State Highway 137 bridge) were made in a downstream direction to "follow the flow" and to minimize general recessional differences that could otherwise occur. The 2016 seepage study indicates main-stem streamflow increases 375 cubic feet per second $\left(\mathrm{ft}^{3} / \mathrm{s}\right)$ from $1,050 \mathrm{ft}^{3} / \mathrm{s}$ at beginning of the study reach (river mile 119.3) to $1,425 \mathrm{ft}^{3} / \mathrm{s}$ at the end of the reach (river mile 79.4). Although most of the streamflow increases are attributed to tributary inflows ( $297 \mathrm{ft} 3 / \mathrm{s}, 79$ percent), $78 \mathrm{ft} / \mathrm{s}$ are attributed seepage gains within the reach. Seepage rates in the study reach ranged from 1.41 cubic feet per second per mile $\left(\left[\mathrm{ft}^{3} / \mathrm{s}\right] /\right.$ mi) (river miles $94.45-108.46)$ to $2.56\left(\mathrm{ft}^{3} / \mathrm{s}\right) / \mathrm{mi}$ (river miles 108.46-119.31), with a mean seepage rate of $2\left(\mathrm{ft}^{3} / \mathrm{s}\right) / \mathrm{mi}$.

Tau values were calculated at 10 sites in the Niobrara NSR study area, and kriging geostatistical techniques were used to develop a contour map that can be used to estimate tau values at locations where streamflow was not measured; therefore, direct calculation of tau is not possible. Tau is a hydrologic index that characterizes the ability of a groundwater system to supply flow to a stream receiving seepage from that system and indicates streamflow dependence on groundwater inflow to the stream. The tau value and other correlated hydrologic indices have been used as explanatory variables to greatly improve the predictive power of low-flow regression equations. The tau value indicates streamflow dependence on groundwater inflow to total streamflow. The minimum tau value was 12.1 days at Willow Creek at Atwood Road near Carns, Nebraska, (USGS station 06463670), and the maximum tau value was 45.5 days at Tyler Falls at Fort Niobrara National Wildlife Refuge near Valentine, Nebr. (USGS station 06461150). Generally, tau values were smaller in the southeastern part of the study area and increased in magnitude in the north and northwest directions.

\section{References Cited}

Alexander, J.S., Zelt, R.B., and Schaepe, N.J., 2009, Geomorphic segmentation, hydraulic geometry, and hydraulic microhabitats of the Niobrara River, NebraskaMethods and initial results: U.S. Geological Survey Scientific Investigations Report 2009-5008, 52 p. [Also available at https://doi.org/10.3133/sir20095008.]

Bentall, R., and Shaffer, F.B., 1979, Availability and use of water in Nebraska, 1975: University of Nebraska, Conservation Survey Division, Nebraska Water Survey Paper 48, 122 p.

Blanchard, S.F., 2007, SonTek/YSI FlowTracker firmware version 3.10 and software version 2.11 upgrades and additional policy on the use of FlowTrackers for streamflow measurements: U.S. Geological Survey Office of Surface Water Technical Memorandum 2007.01, accessed October 2020 at https://water.usgs.gov/admin/memo/SW/sw07.01.html.

Blanchard, S.F., 2009, Application of FlowTracker firmware and software mounting correction factor for potential bias: U.S. Geological Survey Office of Surface Water Technical Memorandum 2009.04, accessed October 2020 at https://water.usgs.gov/admin/memo/SW/sw09.04.html.

Brutsaert, W., 1982, Evaporation into the atmosphere: Dordrecht, Netherlands, Kluwer Academic Publishers, $299 \mathrm{p}$.

Brutsaert, W., 2005, Hydrology—An introduction: Cambridge, United Kingdom, Cambridge University Press, 605 p.

Brutsaert, W., and Nieber, J.L., 1977, Regionalized drought flow hydrographs from a mature glaciated plateau: Water Resources Research, v. 13, no. 3, p. 637-643, accessed April 7, 2011, at https://doi.org/10.1029/ WR013i003p00637.

Buchanan, T.J., and Somers, W.P., 1969, Discharge measurements at gaging stations: U.S. Geological Survey Techniques of Water-Resources Investigations, book 3, chap. A8, 65 p. [Also available at https://doi.org/10.3133/ twri03A8.]

Burchett, R.R., 1986, Geologic bedrock of Nebraska: University of Nebraska Conservation and Survey Division Geologic Maps and Charts 1, scale 1:1,000,000. 
Curran, C.A., Eng, K., and Konrad, C.P., 2012, Analysis of low flows and selected methods for estimating low-flow characteristics at partial-record and ungaged stream sites in western Washington: U.S. Geological Survey Scientific Investigations Report 2012-5078, 46 p. [Also available at https://doi.org/10.3133/sir20125078.]

Dugan, J.T., and Zelt, R.B., 2000, Simulation and analysis of soil-water conditions in the Great Plains and adjacent areas, central United States, 1951-80: U.S. Geological Survey Water-Supply Paper 2427, 81 p. [Also available at https://doi.org/10.3133/wsp2427.]

Eash, D.A., and Barnes, K.K., 2017, Methods for estimating selected low-flow frequency statistics and harmonic mean flows for streams in Iowa (ver. 1.1, November 2017): U.S. Geological Survey Scientific Investigations Report 2012-5171, 99 p., accessed January 2021 at https://doi.org/ $10.3133 / \operatorname{sir} 20125171$.

Eng, K., and Milly, P.C.D., 2007, Relating low-flow characteristics to the base flow recession time constant at partial record stream gauges: Water Resources Research, v. 43, no. 1, art. W01201, 8 p. [Also available at https://doi.org/ 10.1029/2006WR005293.]

Esri, 2001, ArcGIS geostatistical analyst — Statistical tools for data exploration, modeling, and advanced surface generation: Redlands, Calif., Esri, 23 p., accessed November 2020 at https://www.esri.com/library/whitepapers/pdfs/ geostat.pdf.

Fenneman, N.M., 1928, Physiographic divisions of the United States: Annals of the Association of American Geographers, v. 18, no. 4, p. 261-353. [Also available at https://doi.org/ 10.1080/00045602809357034.]

Johnsgard, P.A., 2001, The nature of Nebraska-Ecology and biodiversity: Lincoln, University of Nebraska Press, 402 p.

McGuire, V.L., and Peterson, S.M., 2008, Base of principal aquifer for the Elkhorn-Loup model area, north-central Nebraska: U.S. Geological Survey Scientific Investigations Map 3042, accessed November 2020 at https://doi.org/ $10.3133 / \operatorname{sim} 3042$.

Menne, M.J., Durre, I., Korzeniewski, B., McNeal, S., Thomas, K., Yin, X., Anthony, S.. Ray, R., Voss, R.S., Gleason, B.E., and Houston, T.G., 2012a, Global Historical Climatology Network-Daily (GHCN-Daily), Version 3 [PRCP]: National Oceanic and Atmospheric Administration, National Climatic Data Center, accessed November 2020 at https://doi.org/10.7289/V5D21VHZ.
Menne, M.J., Durre, I., Vose, R.S., Gleason, B.E., and Houston, T.G., 2012b, An overview of the Global Historical Climatology Network-Daily database: Journal of Atmospheric and Oceanic Technology, v. 29, no. 7, p. 897-910. [Also available at https://doi.org/10.1175/ JTECH-D-11-00103.1.]

Mueller, D.S., Wagner, C.R., Rehmel, M.S., Oberg, K.A, and Rainville, Francois, 2013, Measuring discharge with acoustic Doppler current profilers from a moving boat (ver. 2.0, December 2013): U.S. Geological Survey Techniques and Methods, book 3, chap. A22, 95 p., accessed November 2020 at https://doi.org/10.3133/tm3A22.

Nebraska Department of Natural Resources, 2020, Streamgaging stations list-Active NeDNR and USGS stream gages/links to gage data: Nebraska Department of Natural Resources, accessed November 20, 2020, at https:/nednr.nebraska.gov/RealTime/Stations/StationsList.

Nolan, K.M., and Shields, R.R., 2000, Measurement of stream discharge by wading: U.S. Geological Survey WaterResources Investigations Report 2000-4036. CD-ROM. [Also available at https://doi.org/10.3133/wri20004036.]

Paramasivam, C.R., and Venkatramanan, S., 2019, Chapter 3-An introduction to various spatial analysis techniques: GIS and Geostatistical Techniques for Groundwater Science, p. 23-30. [Also available at https://doi.org/ 10.1016/B978-0-12-815413-7.00003-1.]

Qi, S.L., 2010, Digital map of aquifer boundary for the High Plains aquifer in parts of Colorado, Kansas, Nebraska, New Mexico, Oklahoma, South Dakota, Texas, and Wyoming: U.S. Geological Survey Data Series, v. 543, accessed December 2020 at https://doi.org/10.3133/ds543.

Rantz, S.E., and others, 1982, Measurement and computation of streamflow. U.S. Geological Survey Water-Supply Paper 2175, v. 1 and 2. [Also available at https://doi.org/10.3133/ wsp2175.]

Rehmel, M.S., 2007, Application of acoustic Doppler velocimeters for streamflow measurements: Journal of Hydraulic Engineering (New York, N.Y.), v. 133, no. 12, p. 1433-1438. [Also available at https://doi.org/10.1061/ (ASCE)0733-9429(2007)133:12(1433).]

Sauer, V.B., and Turnipseed, D.P., 2010, Stage measurement at gaging stations: U.S. Geological Survey Techniques and Methods book 3, chap. A7, 45 p. [Also available at https://doi.org/10.3133/tm3A7.]

Schultz, S., 2009, Economic and social values of recreational floating on the Niobrara National Scenic River: Omaha, University of Nebraska, final report to Nebraska Game and Parks Commission, 38 p. 
Shaffer, F.B., 1975, History of irrigation and characteristics of streamflow in northern Nebraska: U.S. Geological Survey Open-File Report 76-167.

Soenksen, P.J., Flyr, B.B., Alexander, J.S., and Schaepe, N.J., 2010, Streamflow gains and losses in the Niobrara River Basin, Nebraska, 1980 and 2009: Journal of Environmental Hydrology, v. 18, p. 1-30.

Soenksen, P.J., Miller, L.D., Sharpe, J.B., and Watton, J.R., 1999, Peak-flow frequency relations and evaluation of the peak-flow gaging network in Nebraska: U.S. Geological Survey Water-Resources Investigations Report 99-4032, 48 p. plus appendixes. [Also available at https://doi.org/ 10.3133/wri994032.]

Soller, D.R., and Reheis, M.C., 2004, Surficial materials in the conterminous United States: U.S. Geological Survey Open-File Report 2003-275, scale 1:5,000,000, accessed January 2021 at https://doi.org/10.3133/ofr2003275.

Strauch, K.R., and Soenksen, P.J., 2022, Datasets used to map the base-flow recession time constants in the Niobrara National Scenic River in Nebraska, 2016-18: U.S. Geological Survey data release, https://doi.org/10.5066/ P9PDP1BI.

Tallaksen, L.M., 1995, A review of baseflow recession analysis: Journal of Hydrology (Amsterdam), v. 165, no. 1-4, p. 349-370. [Also available at https://doi.org/10.1016/00221694(94)02540-R.]

Teledyne RD Instruments, 2006, StreamPro ADCP—Shallow streamflow measurement system: Poway, California, Teledyne RD Instruments, 2 p., accessed November 2020 at https://www.comm-tec.com/Docs/Brochure/RDI/streampro_ datasheet_lr.pdf.
Turnipseed, D.P., and Sauer, V.B., 2010, Discharge measurements at gaging stations: U.S. Geological Survey Techniques and Methods book 3, chap. A8, 87 p., accessed November 2020 at https://doi.org/10.3133/tm3A8.

University of Nebraska-Lincoln, Conservation and Survey Division, 1986, Groundwater atlas of Nebraska: Lincoln, University of Nebraska, Conservation and Survey Division, Resource Atlas no. 4. 32 p.

U.S. Department of Agriculture, Natural Resources Conservation Service, 2008, Watershed boundary dataset for HUC 101500, Nebraska: Natural Resources Conservation Service digital data, accessed October 2020 at https://datagateway.nrcs.usda.gov.

U.S. Geological Survey, 2020, USGS water data for the Nation: U.S. Geological Survey National Water Information System database, accessed November 2020 at https://doi.org/10.5066/F7P55KJN.

U.S. Soil Conservation Service, 1970, Major land resources area (MLRA): Adapted from the U.S. Soil Conservation Service by the U.S. Geological Survey, accessed November 2020 at https://water.usgs.gov/GIS/metadata/ usgswrd/XML/mlra.xml.

Zecharias, Y.B., and Brutsaert, W., 1988, Recession characteristics of groundwater outflow and base flow from mountainous watersheds: Water Resources Research, v. 24, no. 10, p. 1651-1658. [Also available at https://doi.org/10.1029/ WR024i010p01651.] 

For more information about this publication, contact: Director, USGS Nebraska Water Science Center 5231 South 19th Street

Lincoln, NE 68512

402-328-4100

For additional information, visit: https://www.usgs.gov/ centers/ne-water

Publishing support provided by the

Lafayette and Rolla Publishing Service Centers 


\section{$\frac{\mathbb{3}}{3}$}

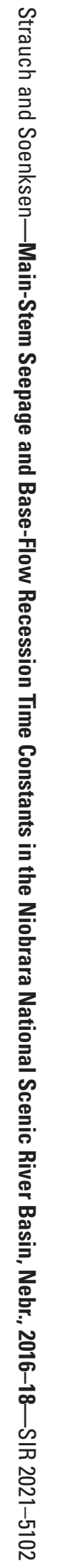

